\title{
"Framing" the End of the Social History of Medicine
}

\section{Roger Cooter}

Apart from involving me in something close to writing my own obituary, framing the end of the social history of medicine is difficult for the simple reason that the subdiscipline's roll into the grave was far from obvious or straightforward. The end was more in the manner, literally, of a passing-a sluggish, uneventful meltdown, nowhere much noticed or commented on. Indeed, the walking dead are still many among us: explicitly "social" histories of medicine continue to be written, and undergraduate courses in the social history of medicine (not to mention a journal by the name) continue to be subscribed to. This is odd because, in somewhat more than literal fashion, the end was heralded over a decade ago when Charles Rosenberg-the acknowledged doyen of the field-proposed the banishment of "the social" in the social history of medicine and its replacement with "the frame." ${ }^{1}$ The substitution was widely endorsed. ${ }^{2}$ However, the expressed motives for it (as well as the unexpressed ones I will come to) were different from the historiographical ones that might have been posed. Thus, the actual ending of the social history of medicine was obscured at the same time as the literal ending was (in that other sense of the word) "framed." Such is my contention. This chapter, therefore, is mainly concerned with the wider context 
for the demise of "the social" in the history of medicine-with what might be styled (though I wish to imply no conspiracy) the framing of the framing.

That our concern has to do with more than merely the substitution of words first became apparent to me in the mid-1990s when I was approached to write a social history of medicine. The prospect was enticing. Here would be a chance to pull together some of the many different themes that had come to comprise the field: the politics of professionalization, alternative healing, the study of patient narratives, welfare strategies, constructions of sexuality and gender, madness, deviance, diseases and disability, public health and private practice, ethics, epidemiology, experimentation and education, tropical medicine and imperialism, along with the various actual and rhetorical relations between medicine and war, medicine and technology, medicine and art, medicine and literature, and so on. More than that, the book would afford an opportunity under such headings, chapter by chapter, to review how, over the past two or three decades, historical and historiographical understandings had broadened, sharpened, and deepened. There was need for such a book, and there probably still is. But when pen came to paper, paralysis set in. The problem wasn't the survey of the literatures involved, formidable though they had become. Rather, it was more the nature of, and need for, the overall packaging. A social history of medicine? In 1992, Andrew Wear proudly declared that it had "come of age," to which Ludmilla Jordanova roundly responded that it was "still in its infancy."3

What caused my pen to falter, though, was the realization that somehow, somewhere along the way in the 1980s and 1990s, all the key words had lost their certainty of meaning, and some (pace Rosenberg) had even been threatened with excision. No longer could they be taken for granted: "history" and "medicine," no less than "the social," had become deeply problematic. The hinges of the triptych were rusting up and coming unstuck; historiographically, the whole was no longer the sum of its elemental parts. Such a realization was more than a little worrying politically, inasmuch as the implied loss of disciplinary coherence could only disable the critical, if not socialist, thrust of an enterprise that had been honed over the previous quarter-century in alliance with social medicine, medical sociology, and social history-an unusual mix of radical politics and policy, critique and theory, and empirical practice, represented by Thomas McKeown, Ivan Illich, and E. P. Thompson, respectively.

I have no desire to defend the use of "the social" in the social history of medicine. It might be as well to admit that the subdiscipline has had its day, done its bit, much in the manner of older forms of political and economic history. Given that much social history of medicine has been intellectually flatfooted and theo- retically unreflective-at best revisionist, at worst dominated by empiricism and even scientism (if a vast number of demographic contributions are taken into account)-moving on may be no bad thing. The intention here is more modest: merely to capture something of the wider intellectual context that has in fact necessitated this moving on and ought, I believe, further to inform it. Thus, this chapter has been conceived mainly as a record of what happened, a chronicle of an "ending" insofar as history (the business of history writing) ever has closure. ${ }^{4}$ It seems worth doing, for while the history wars have been conducted over the past few decades as vigorously as the culture wars and the science wars of which they are a part, it is not at all clear what exactly has changed, or how and why. Least of all is this clear to new entrants to the history of medicine.

Admittedly, exactitude is easier called for than accomplished, given the almost ineffable (for being so recent, radical, and multifaceted), inevitably partial, and certainly very messy nature of the context within which the meaning and practice of history writing has been challenged. For these reasons, among others, it is not possible to provide anything like a social constructivist account of the historiography of the end of the social history of medicine-an analysis, that is, in terms of a situated body of knowledge mediating socioeconomic and political interests. (The subdiscipline was never "schooled" enough for that; indeed, it was always in tension with the aspiration to de-ghettoize itself by merging into the historical mainstream.) Nor, for essentially the same reasons, is it possible to provide either an analysis of the discourse of the historiographical body or a deconstructivist, semiotic account of "the text," since neither the infrastructural body nor the text as such exist. We can, however, lay out some of the features of the subject's problematization with reference to its wider intellectual and, to some extent, sociopolitical context. This is easiest done by focusing first on the key words, starting with "medicine" itself. We can then turn to an analysis of Rosenberg's article on framing, locating it within the politics of historiographical change. Finally, by way of a postscript on the postmortem, as it were, some observations can be tendered on the possible place of "the social," "the political," and "the medical" in history now.

\section{"Medicine," "History," and "the Social"}

"Medicine" has always been troublesome, if one stopped to think of it. Recently described by John Pickstone as a convenient omnibus term, resembling in this respect "agriculture," or maybe "engineering" or "electronics," it invariably consists of more than merely the professional practice of licensed healers in all 
their economic, political, and social settings. It is more, too, than just the knowledge of diseases and processes affecting the body in sickness and health and the prevailing technologies for corporeal intervention. ${ }^{6}$ Worldviews and ideologies like humoralism, evolutionism, and environmentalism or Christianity, communism, and fascism have necessarily been as much a part of it as more specific sets of shifting discourses, rhetorics, and representations. "Cultures of healing" and "healing in culture" as objects of study can be as conceptually broad or narrow as the analyst chooses to make them. As knowledge and as practice, medicine (like religion) can be experienced at the most intimate level of being and politics, as well as, simultaneously, through precipitates from the highest reaches of global ideology and economics. And not just "experienced" in any simple sense; as Foucault appreciated, medical sites and personnel historically have been bound up with mutations of political thought into their modern governmental form. In the course of such processes, individuals have come to describe. themselves in the languages of health and illness, and to accept the norms of "the normal" and "the pathological" as the basis for circumscribing their mortal and moral existence. ${ }^{7}$ Obviously, then, as Jordanova has insisted, we cannot treat medicine simply as knowledge, or merely as "another form of science."

At root, medicine is about power: "the power of doctors and of patients, of institutions such as churches, charities, insurance companies, or pharmaceutical manufacturers, and especially governments, in peacetime or in war." ${ }^{\prime \prime}$ Recently, however, there has been a seismic shift in the nature and exercise of the powers that constitute "medicine." Whether our gaze is on the disarray of health services n post-cold war Eastern Europe, China, and the poorer countries of postcolonial Africa, or on the fast-changing reorganization of medical systems in the West, hings look far different from what they did ten or twenty years ago. Crucially, velfare medicine has been felled. National health services now embrace the logic of private, multinational corporations. ${ }^{10}$ In Britain's National Health Service this hinking is evident in the adoption of private finance initiatives for the building of new hospitals and the turning of general practitioners into NHS "fund holders" perating according to the rules of internal markets. The shift is further made pparent and exercised through the emphasis since the 1980s on "evidence-based nedicine," the mechanism enabling the state to pay only for treatments for vhich there is statistical evidence of benefit-a concept and practice of particular ppeal to managers and accountants. Many of these changes have been pioneered $x$ the United States, where doctors now queue to obtain degrees in business dministration in order not to be irrelevant in the so-called medical reform proess. ${ }^{11}$ As this suggests, fears by the medical profession (especially in Britain and the United States) of losses of autonomy no longer stem directly from the state, as they were thought to in the past, but from the rationalizing forces of business management, albeit encouraged by governments. In the United States, more than one-half of all doctors are now salaried employees of medical corporations, and the consequent rhetoric of an "embattled profession" has been taken as compelling evidence of the decline of professional authority in general. ${ }^{12}$

Professional authority-power-in medicine has also been seriously challenged by outside interference in the hitherto professionally sacrosanct area of clinical decision-making. Both cost-calculating managers and evidence-weighing governments now act as third parties in such decisions, even though doctors remain the principal targets of complaint in what they perceive as a "culture of blame." Through sensational exposure of medical malpractice and incompetence, further reason is found for withdrawal of the state's former compliance in the profession's self-regulation (existing in Britain since the Medical Registration Act of 1858). Now, the profession's ethical governance is increasingly given over to the courts through legal regulation.

Such redistributions in the power around medicine are reflected in, and inseparable from, equally profound changes in doctor-patient relations-to the extent that the word "patient," too, has lost much of its certainty of meaning and has become open to contestation..$^{13}$ In the face of fragmentation, depersonalization, and multiprofessionalization in the delivery of medical care, calls have been made for "narrative-based medicine," the ethics of which allege "the primacy of the patient's voice." ${ }^{14}$ Meanwhile, increasing numbers of "health consumers" have turned to untested therapies by unregulated practitioners while at the same time demanding more evidence-based regulated medicine. Many of the same health consumers (wealthy, white, and Western for the most part) partake in what Roy Porter once dubbed the "MacDonaldization of medicine." 15 They demand as a "right" the freedom to shop unfettered in the "supermarkets of life," picking and choosing reproductive technologies as readily as vaccines, kidneys, hearts, and assisted suicides. Much of the laity has also been medically reskilled and empowered through web sites and illness support-groups, and it now comes to act as a jury for a medicine on trial. ${ }^{16}$ Clearly, in the pluralized medical marketplace there is not one but multiple sources of authority, and the idea of the passive patient is noticeably passé.

This rearrangement of power is further reflected in the refutation by some medical ethicists of the very existence and operation of a universalistic morality, such as that purported for the late twentieth century by the philosopher John Rawls. The idea of a moral consensus (Rawls's "reflective equilibrium") presup- 
posed social homogeneity. But this has become increasingly difficult to imagine and decreasingly desirable to sustain in liberal democracies where multiculturalism and multifaith are hyped as politically correct. Hence, in theory at least, different, equally "rational," interpretations of what is medically ethical have come to coexist based on religion, culture, and ethnicity. ${ }^{17}$ Alongside, and not entirely separate from, this development has been the undermining of the instrumental rationality of modern medicine. Models of linear progress, and belief in rational control over the processes of medicine, have been seriously eroded by the manifestation of previously unforeseen risks and the negative side-effects of biomedical "progress"-erosions that mark, in Ulrich Beck's terms, the shift from "simple" to "reflexive modernity."18 Once these risks began to be registered in the minds of insurance companies, medical professionals, medical management teams, the state, and potential individual "clients," the would-be rationality of biomedical research began to be demystified and demonopolized. (Contributing to this view was a heightened awareness of how multinational and monopolistictending pharmaceutical companies controlled much of the research, as well as the allocation of products.) Increasingly, the public began to decide between different plausible or probable scientific claims. In this situation, as has been pointed out in reference to the pressures for redefining brain death, political groups came to make use of scientific expertise and counter-expertise in order to push forward their own favorite practical and legal solutions. ${ }^{19}$

Unsurprisingly, such fundamental change in the relations, organization, consumption, and overall conception of modern medicine has had an impact on how medicine is thought about historically. Specifically, the notion of the social control of docile bodies, which was basic to the social history and historical sociology of medicine as it developed in the 1970s and 1980s, has come to seem dated as an analytical imperative. No longer is it quite so obvious to regard medicine simply as a powerful means of imposing social order though "disciplinary normalization." Perhaps in the past as in the present, the relationship between medicine and the laity entailed wider interactions between self, society, and knowledge, all according to competing priorities and the different material constraints of everyday life. ${ }^{20}$ To arrive at this conclusion in no way necessitates discarding Foucault's insights on the crucial role of modern medical language and practice as a medium for the policing and self-policing of bodies and desires. Required, rather, is discarding crude or vulgar histories of medical surveillance, social control, and the deskilling of patients-1970s and 1980s contributions to the historical narratives of professionalization and medicalization. In part, these narratives were hoist on their own petard in the 1980s and 1990s when the self-serving antiprofessionalism of radical feminists and critics came to support dialectically the interests of free market ideologues and antiabortionists, along with eco-activists, neofascists, ravers, "hacktivists," and the others who now make up "do-it-yourself" culture. ${ }^{21}$

Although medicine as an epistemological and discursive concern should not be conflated with medicine in the service of professional power, it is fair to say that the very idea of "medicine" or "the medical" has been destabilized. As Nikolas Rose has pointed out, "What we have come to call medicine is constituted by a series of associations between events distributed along a number of different dimensions, with different histories, different conditions of possibility, different surfaces of emergence." 22 Medicine is no longer the self-contained entity that it once seemed; as it is technically more complex, so it is correspondingly more multifocal and multivocal in its material relations. Its boundaries less clear and more porous than formerly thought, it consequently has become less sharp a category for analysis. In extending everywhere, it might be seen as everything and nothing-like Foucauldian "power," everywhere and nowhere. What, then, is the thing to which the analytical tool of history is to be applied? And how can medicine be an analytical tool for the history of society? Not only were all the assumptions that historians made about medicine in the 1960s and 1970s with respect to the state, professional power, and science called into question by the realities of the 1990 s, ${ }^{23}$ so too was the very object or category of study.

And "history"? While it may be true that "from the time of Herodotus and Thucydides, historians have vehemently disagreed about the purposes, methods, and epistemological foundations of the study of the past," ${ }^{24}$ before the 1980s and 1990s these debates were never so extensive or intensive. Echoing Marx, Robert Putman in 1993 insisted that "history matters" because "individuals may 'choose' their institutions, but they do not choose them under circumstances of their own making, and their choices in turn influence the rules within which their successors choose." 25 Of course. What was new in the 1980s and 1990s was the urgency to defend this commonplace-not against an old, reactionary right, or against a perceived-to-be overdeterministic ("choice"-denying) Marxist left, but against a radically iconoclastic postmodern avant-garde of philosophers, literary theorists, and cultural critics. According to these, history was nothing more than the "invention" of historians dealing in images and representations of the past to which they could not possibly have any direct access. Further, the much-loved periodization of historians was nothing more than a strategy for narrative closure. Thus, historical "truth" and historical practice were to be regarded as no less 
contingent and subjective ("shaped not found") than the scientific "truth" discerned by sociologists of scientific knowledge. In new and more extreme ways than in the past, the old hoary question of objectivity was back on the agenda. ${ }^{26}$

Professional historians were stunned and deeply threatened by such attention to their methods and assumptions. A torrent of defensive publications were issued by (to name but a few) Arthur Marwick; Bryan Palmer; Joyce Appleby, Lynn Hunt and Margaret Jacob; Richard Evans; Geoff Eley; Eric Hobsbawm; Raphael Samuel; and Gareth Stedman Jones. ${ }^{27}$ Despite the very different political orientations of these historians, they all shared some of the same professional and political suspicion of "postmodern postures," ${ }^{28}$ while to differing degrees confessing to their own complicity in the old rationalist and increasingly demoralized Enlightenment search for objectivity. As the political culture veered to the right, confusion, apathy, and uncertainty set in.

Nor was the "postmodern challenge" 29 the only cause for concern. In new and far more extensive ways than in the past, "history" (like medicine) was being "managed" in both crude and subtle ways by contending communities of opinion-a feature of the present to which, in fact, postmodern writers drew attention. In the museum in the bowels of the Statute of Liberty, as in countless other public sites, political battles for control over representations of history were fiercely fought. ${ }^{30}$ Allied to this (again not unlike in medicine), history was increasingly subject to naked market forces, both within the academy (for example, though assessment exercises linked to research funding), and outside it in the expanding commercial heritage and leisure industries. ${ }^{31}$ Ideologically hand-in-hand with the "rationalization" of history departments went the global expansion of capitalintensive "Disney history," the latter providing the new discipline of museology with an unlimited supply of case studies in the manipulation of historical representation. Forces of a slightly different nature, more sinister for being less public, were also at work in the history panels of grant-giving bodies, not least in the history of medicine. Increasingly, the tendency of such bodies was away from humanities-style appraisals to more science or social science models, with emphases on practical applicability, "relevance" (to short-term political interests), directed goals, and publicly accessible outputs. In Britain especially, the idea of the historian as a devoted, critically minded intellectual was increasingly derided as a relic of ivory-towered times. The fetid breath of managerialism hung heavy.

As for "the social," by the mid-1980s it was deemed by Francophone semiologists as absorbed into "the cultural." ${ }^{32}$ A decade later, the prospect of an "end of social history" had not only been raised, it had been realized. ${ }^{33}$ In what superficially appears in retrospect as an intellectual parody of the thinking of the then dominant political parties, Francophone poststructuralists thoroughly underpinned Margaret Thatcher's would-be class consensual claim that "there is no such thing as society." Although Thatcher and her free market cronies were scarcely like Jean-François Lyotard and his disciples in their quest to deprivilege the economic and the political, the effect was much the same: "a loss of political appetite for the old frameworks of social analysis" ${ }^{\prime 34}$ and, in particular, for the validity and relevance of Marxism. ${ }^{35}$ While the new political elite effected their ideological cleansing in the name of a new "end to ideology, ${ }^{136}$ poststructuralists put to flight all notion of structure, agency, and social determinism. Operating from the aesthetic critique of modernity first elaborated by Nietzsche in the late nineteenth century, the French "new philosophers," as they were often called in the English-speaking world (notably, Jacques Derrida, Giles Deleuze, Lyotard, and Jean Baudrillard)-or the "young conservatives" as Jürgen Habermas referred to them because of their abandonment of all hopes of social change ${ }^{37}$-demanded freedom from political forms of life and the rejection of the "tyranny of reason," technocratic rationality, and the old emphasis on the economic. ${ }^{38}$

Although the pre-"postmodern" Foucault-the Foucault concerned with liberating the revolutionary process from ritualized and dogmatized Marxism ${ }^{39}$-had only invited consideration of whether power was "always in a subordinate position relative to the economy, ${ }^{\prime 40}$ Derrida and other linguistic deconstructivists argued forcefully for the impossibility of reducing technologies of violence to instrumental political power, economic interests, and social control. ${ }^{41}$ The Foucault of Surveiller et punir: Naissance de la prison who appeared to offer a critique of capitalism ("it is largely as a force of production that the body is invested with relations of power and domination" $)^{42}$ was increasingly refashioned as an avant-garde literary theorist. ${ }^{43}$ This other Foucault, identified largely with the Histoire de la sexualité, doubted that power was always in the service of, and ultimately answerable to, the economy. Instead, he insisted on the grandiloquence and rules of discourse as constructing bodies. ${ }^{44}$ Here, as everywhere in what became the flight into cultural studies, sociological categories were dust-binned in favor of semiotic ones, which were often inflected psychoanalytically, as in the bogey of "narrative fetishism." The master narratives of modernity provided by Marx, Durkheim, and Weber were shed through the literary turn to the discursive-what Bryan Palmer dubbed the "descent into discourse." 45 Although sophisticated Marxist theoreticians, such as Ernesto Laclau, were as involved as anyone in deconstructing "society" as an intelligible and essentialist totality, ${ }^{46}$ it was above all literary and linguistic theorists who compelled Western intellectuals to problematize the relationship between discourse, structure, and knowledge and to question whether "structure" 
and "knowledge" had status at all within the analysis of discourse. ${ }^{47}$ It was they who compelled historians to attend to the historicity of concepts such "class," "the people," and "the social"-that is, to see them not as inevitable, natural, or god-given but as historical products that had become "naturalized" over time.

Thus, while capitalism restructured itself monopolistically and globally in the wake of the collapse of socialist modes of production and social systems, while Islamic fundamentalism arose and ethnic cleansings swept the planet, and while (closer to home) the academic job market shrank from its 1960s heyday, Western intellectuals were increasingly inclined to reflexivity, the play of signifiers without referents, free actors, representations, "irreducible ambiguities," and evocative explorations into the interrelations, reverberations, and tensions within and between disparate political and fictional genres. ${ }^{48}$ Within the professional practice of history, in the face of despair at the collapse of the old totalizing social discourses, there emerged compensatory fascination with constructions of identity, interiority, and other "imaginative geographies." As the language of historians became more subtle and self-referential, the more the cord to political action was severed. Having come to doubt the modernist interest in politics and rationality, intellectuals were impaled on the spikes of their own profound sense of skepticism and powerlessness. In cultural studies, at the same time as an emancipatory politics was raised to new heights through the pursuit of differance or "the Other" (abetted much by the work on gender and "orientalism" of Donna Haraway and Edward Said, among others), ${ }^{49}$ the difference between murder and murder fiction was not only increasingly blurred (as Robert Darnton was overheard to remark), ${ }^{50}$ but, thanks in part to Hayden White, was ceasing much to matter. By some reckonings, the abattoir and Auschwitz were not a great deal different historically, and "the body"-resurrected not merely as a textual site of contestation and struggle but the locus on which power was to be seen as inscribed (that is, outwith a framework of social class and race, or even social context) ${ }^{51}$ became so discursive, flexible, and fragmented as to be immaterial.

All "reality"-not just messianic historical materialism-was in a hopeless mess, ${ }^{52}$ whether or not (à la Baudrillard) one saw it as having given way to virtual reality or to a "hyperreality" of endless copies without originals (with the video as the icon). Power was no longer something found at the end of a gun or under the heel of a boot, or even something negotiated through the exercise of social relations in a material world. It was now a monolithic object dispersed through discursive fields of knowledge production. All the world had become a text, the author of which was unclear and of no great concern. Along with the concepts of "class" and "society" and other such scientific pretensions of modernity, "ideol- ogy" (however devulgarized) virtually disappeared from the historical vocabulary. By Francis Fukuyama's The End of History and the Last Man (1992), which in fact contested the notion of a new consensual "end of ideology" in politics, social history as the forum for the study of such things was an embarrassed bygone-a residue on the outer edges of a vastly expanding and hyperinflating, pastichereducing, postmodern marketplace of infinite diversity, eclecticism, and discontinuities (in some eyes, anarchic, nihilistic, and narcissistic, if not entirely weightless, decorative, and commercial). Certainly social history's political anchor was weighed by it. Already by 1980 the political thrust of the social history seeded by E. P. Thompson was perceived as "marooned on a sea of increasingly diffuse cultural analysis." 53 By 1990, the tide had overwhelmed it; like the "social," it had sunk into salient silence.

Not only in history generally but specifically in relation to the history of medicine, there was no call for "the social." On the contrary; reviewing twenty-five years of the Society for the Social History of Medicine in 1995, Dorothy Porter dealt in understatement when she concluded that "New historiographical trends in cultural history may make a society dedicated to the social history of medicine redundant." ${ }^{54}$ Jordanova in "The Social Construction of Medical Knowledge," published in the same issue of Social History of Medicine as Porter's paper, suggested a disciplinary relabeling to "what might best be called a cultural history of medicine." ${ }^{55}$ Lynn Hunt's New Cultural History (1989) may have been more in mind than the likes of Jonathan Sawday's The Body Emblazoned (1995), Judith Butler's Bodies that Matter (1993), Elizabeth Grosz and Elspeth Probyn's Sexy Bodies (1995), Athena Vrettos' Somatic Fictions (1995), and the psychomedical studies of visual and literary representations of disease and illness pioneered and pursued above all by Sander Gilman. ${ }^{56}$ But by then, Foucault was under everyone's skin, whether you liked it or not; ${ }^{57}$ beyond sex and madness and far into the intricacies of gender, literary-turned-cultural excavations of the body were extending rapidly. Grumbling there was, and criticism too, such as at the disconnection of the critical analysis of modernist mentalities from the historical and sociological examination of modernity itself. ${ }^{58}$ But, without doubt, the pundits of what was nebulously referred to as the New Historicism in literary and cultural studies (main domicile Berkeley, main journal Representations) had taken the sunshine from social historians of medicine while borrowing their wares. The "somatic turning" mopped up, providing "a new organizing principle within Anglo-American intellectual activity." 59

Body studies were in many ways the epitome of the linguistic turn in cultural studies, $^{60}$ and they were fundamentally at odds with social histories of medi- 
cine, however constructivist, Foucauldian, and contingent-emphasizing the latter might aspire to be. This was not simply because they engaged with synecdoche, metaphor, analogy, "close reading," and other techniques honed in English departments. Nor was it because they privileged texts over contexts and preferred to deal with inscriptions of modernity on the body and embodied cultural practices over narratives of modernity in medicine and health. (To a degree, the pioneering social historians of ideas in science and medicine, Owsei Temkin, George Rosen, and Erwin Ackerknecht, might be accused, or praised, for having done similar.) No, somatic studies challenged social histories of medicine because they undermined the reductive or determinist assumption at their heart-the notion that everything is ultimately socially constitutive. Following Derrida, somatic studies asserted, on the contrary, that nothing is reducible to anything (while proceeding to reduce most everything to discourse). The thinking was not only nonpositivist and nonteleological (as in the best social history of science and medicine) but nonontological: fundamental or absolute structures, inalienable human natures, and essentialist categories like "society" were denied; everything was to be seen as emergent or immanent. "Instantiation" became a favored word.

Social historians of medicine could thus be accused (as by Patrick Joyce) of intellectual naïveté for treating the body merely as a corporeal entity and for failing entirely to recognize "the social" as itself a product of modernity. ${ }^{61}$ Even in their most novel pursuits (such as the "understudied" experiences of patients and the role of the laity in medical practice), ${ }^{62}$ social historians of medicine were left to look like mindless empiricists-a look particularly fixed on the faces of those unschooled in Foucault and the epistemology and sociology. of scientific and medical knowledge, whether à la Frankfurt, Edinburgh, or Paris. Retreat was on the cards. At best, market-wise social historians of medicine sought to put old wine into new bottles through books and courses relabeled "the body." 63

By the 1990s, moreover, there appeared no longer to be any need for the "social" in the social history of medicine. According to Charles Rosenberg in 1989, enough had been written to convince all but the most moronic that "every aspect of medicine's history is necessarily 'social' whether acted out in laboratory, library, or at the bedside." ${ }^{64}$ Since this "all-is-social" theme had been the historiographical mission of the context-celebrating subdiscipline since the mid-1970s, there was no need to go on about it. Mission accomplished. As Rosenberg submitted, the "social" in the social history of medicine and science had become tautological-"as tautological as the 'social construction of disease.' " Harking back to Erving Goffman's Frame Analysis (1975), Rosenberg proposed that we speak instead of "framing disease." This then became the main title of the edited volume in the cultural history of medicine in which his 1989 essay was reprinted. Thus, social historians of medicine, far from being forced into historiographical worry over the retheorizing of "the social," were provided with a means to ignore it while carrying on business as usual.

As I have said, it is not my intention here to defend "the social" in the social history of medicine; I merely wish to register the synchronicity of the postmodern turn outlined above with Rosenberg's insistence on exchanging "the social" for "the frame." Arguably, the contextualization of his essay on framing disease is as important as the historiographical claims made within it, and as important as the possible impact of those claims on the writing of the history and historical sociology of medicine (so that now, ironically, we find the writing of social constructivist accounts of disease left to members of the medical profession). ${ }^{65}$ Rosenberg's essay deserves close attention, then, despite the fact that it was neither intended nor received as an important theoretical paper.

\section{Rosenberg's Frame}

Written in the late 1980s for the policy outreach journal the Milbank Quarterly, the immediate context of Rosenberg's essay was the intellectual burden imposed by AIDS. Indeed, only a few years before, Rosenberg had written specifically on this subject for the same journal. ${ }^{66}$ To many observers, the biological realities of AIDS confounded the assertion of diseases as "mere" social constructs. As such, Rosenberg's essay was also an intervention in the much wider and more heated "science wars" between the defenders of scientific realism, rationalism, and Truth, on the one hand, and the philosophers and sociologists of science promoting varieties of relativism, on the other.

Although Rosenberg's essay did not touch on contemporary controversy over the extreme relativism of the literary deconstructivists that challenged the sacred objectivity claims and assumptions of historians, to some extent that backdrop was understood. In the late 1980s, discussion of relativism was extensive, especially in America, and especially among historians-in part because of a debate unleashed in 1988 by Peter Novick's magisterial history of the "objectivity question" in the practice of American history. ${ }^{67}$ The fourth and final part of Novick's book, "Objectivity in Crisis," recorded an experience that was only too familiar to those like Rosenberg in departments of the history and sociology of science where post-positivist distinctions between fact and value; science, scientism, and ideology; nature and culture; and biology and society had been much discussed, especially after the publication in 1962 of Thomas Kuhn's Structure of Scientific Revolu- 
tions. In such places, Lyotard was received not simply as another postmodern philosopher but as one claiming to pronounce specifically on the nature of science. (Dependent in part on the insights of Kuhn and philosopher of science, Paul Feyerabend, Lyotard's claim in The Postmodern Condition: A Report on Knowledge [1979; translated, 1984] was that science was no longer in the business of truth-seeking but rather in the manufacture of incommensurable theories. ${ }^{68} \mathrm{As}$ everywhere, these debates were emotional, increasingly public, and politically charged. ${ }^{69}$ Indeed, there was more than a whiff of McCarthyism to them. Setting the pace, Hilary Putnam in Reason, Truth, and History (1981) saw the cutting edge of relativism as deriving explicitly from Marx, Freud, and Nietzsche, who taught that "below what we are pleased to regard as our most profound spiritual and moral insights lies a seething cauldron of power drives, economic interests, and selfish fantasies. ${ }^{\prime \prime 70}$ By the 1990 s, relativism of any type or strength was tending to be equated with radical relativism and to have many of the same "damning associations as Communism, whether you're a party member or not." 71

Rosenberg's essay was by no means simply a reactionary response to the alleged naked biological realities of the disease that smote Foucault. A moderate relativist himself, Rosenberg was fully aware of the provisional nature of knowledge. His essay can be read, rather, as an effort to deprivilege "radical" or "hyper"relativism and hence spare the social history of medicine, and social constructivism in particular, from the arrows of political outrage then surrounding it. Necessarily, therefore, in this context, the renunciation of "the social" and its replacement with "the frame" was a calculated political act; the verb "to construct" was in fact being substituted by "to frame" as "a less programmatically [i.e., politically] charged metaphor." ${ }^{\prime 72}$ While shifting attention away from the political implications of social constructivism, Rosenberg's "frame" emphasized the relations between biological events and their individual and collective experience and perception. In other words, it was as a strategy both for a compromised relativism and for a pluralistic approach to history. Through "framing," the fragments of historical evidence might be disciplined but not overnarrativized; likewise, agency could still be ascribed to social, economic, intellectual, and political forces without granting overdeterminacy to any of them, and the role of individuals could be preserved. (Rosenberg's harking back to Goffman's use of the frame should not therefore be regarded as incidental, since Goffman had held to a social constructivist view of the self. $)^{73}$ As a descriptive category, "the frame" avoids responsibility being attached to any particular interest group or set of historical actors (including historians). ${ }^{74} \mathrm{~A}$ versatile metaphor, then, "the frame" has the look of structure but commits one to no particular theoretical architecture or politics.
Yet, by these very means, and in common with a great deal of American neoleft liberalism, Rosenberg's formulation can be seen as a part of an effort to return to a "commonsense" pragmatism around which consensus can be built. In that sense, it can be regarded as part of an act to reframe the writing of the history of medicine within a political philosophy that, while it may not be as ideologically distinctive as Marxism, is no less ideological. One of the characteristics of this political philosophy is to make any retreat from it impossible by burning all the bridges to the old conceptual machinery while purporting (to a degree) to incorporate them. It is noteworthy how Rosenberg in his essay both praises the pioneering social history of medicine of the socialist Henry Sigerist (to illustrate how social history can be written without regard to relativist social constructivism), even as he draws attention to the antiquated positivist nature of Sigerist's regard of medical knowledge. Links between medicine (and the production of medical history) and politicoeconomic purpose are thereby, in effect, dismissed as vulgar (positivistic) Marxism, at the same time as (to cite Simon Schaffer dealing with the same "facetious blackguarding" in the history of science), over-robust "connections between natural knowledge and social interests are damned as sociological relativism." ${ }^{\prime 75}$ Note, too, that Rosenberg's highly qualified endorsement of the provisionality of knowledge ("Knowledge may be provisional") is made in the course of staking a claim for his own historical revision (" . . but its successive revisions are no less important for that"). ${ }^{76}$ This maneuver conforms to what Stuart Hall has called the "discursive struggle" over the delegitimation of opposing ideologies (or discourses), where the "older" machinery is presented as, at best, "optional." In common with the postmodernists critiqued by Fredric Jameson, it's all within the spirit of pluralism: "As with so much else, it is an old 1950s acquaintance, 'the end of ideology,' which has in the postmodern returned with a new and unexpected kind of plausibility." 78

Thus, Rosenberg's pseudostructural notion of "the frame" might appropriately be described as "within the frame" of the depoliticizing thrust of Francophone postmodernity. Given that "framing" was also a concept deployed by the antirealist Derrida for deconstructivist purposes, ${ }^{79}$ it is tempting to suggest some closer affinity. The temptation must be resisted, however, for no two projects were less alike philosophically and practically. Nevertheless, Rosenberg's framing does go with the loosely Foucauldian (skeptical-relativist) culturalist flow. Without entirely dismissing either the social constructivist approach to medical knowledge, or the left-wing political tradition behind both social medicine (from Ryle to McKeown) and the social history of medicine (from Sigerist to Charles Webster and beyond), the notion of framing occludes both while appearing merely to 
encourage the historical analysis of yet more "full and appropriate contexts. ${ }^{180}$ If the production of historical and historiographical knowledge is but one form of the production of knowledge that accompanies the restructuring of capital (along with the restructuring and rearticulation of practices), ${ }^{81}$ then the substitution of "the frame" for "the social" in the history of medicine may be regarded as constitutive. Perhaps this is only to state the obvious: that, to mimic Marx, Gramsci, and Putman, historians don't choose their history under circumstances of their own making. That the act of writing history creates texts and constructs knowledge seems obvious, but there is never an intellectual free market (any more than there is a "free" economic one). Like Rawls's assertion of an ethical consensus for the late twentieth century, or Thatcher's "end of society," the would-be historiographically hegemonic-the invented "consensual"-must inevitably do political work, if only through the process of occluding. The displacement of "the social" by "the frame" was one such act.

This is not the only way to think about Rosenberg's "frame." As germane might be a view of it as seeking to reembody a history whose analytical categories had become destabilized-as destabilized (or generally messy) as the medicine and society of "late capitalism." Thus, the illusion of "the frame" may be less that of structure than that of stability, and less that of a totalizing contextual view than that of putative coherence. The warm embrace of the idea of the frame by historians of medicine in the 1990s might be explicable in terms of this illusion; at the very least it enables writing the history of medicine without having seriously to question the terms of analysis. It places a comforting blanket over the conceptual diaspora of modern history. This partly explains why Jordanova's call to render the social history of medicine a territory for critical engagement and debate has gone largely unheeded..$^{82}$ Jordanova, in effect, sought to explore the categorical messiness of the historiography of medicine as it was emerging in the 1990s. Hers was an invitation to reexamine the repertoire of categories supplied through the social history of medicine's response to the old positivist and doctor-centered, or tribal legitimating history of medicine-categories such as medicalization, professionalization, culture, representations, health, disease, hygiene, sexuality, and the family. Rosenberg's "frames," on the other hand, can be seen as the effort to put some kind of lid on that messiness and its investigation-in part to contain, in part to avoid the ever more apparent instability of the categories. If Jordanova's mission was one of disciplining the social history of medicine and bringing it to "maturity," a part of Rosenberg's strategy was to avoid the subdiscipline having any crisis of identity.

\section{Post-Frame, or the End of the Beginning of the End}

History, it might almost be said, has rendered the frame as superfluous as "the social" it sought to replace. The conditions for its possibility have surrendered to others, on the whole less politically despairing and historiographically fraught. This is not to suggest that with the change of millennium the slate has been wiped clean, the epistemological agonies of the last two or three decades magically erased. On the contrary, notched-up but still grating against the old modernist certainties and categories of "social" analysis are such postmodern insights as that on the impossibility of sustaining universal categories and truths (like "the social"); the fallacy of essentialism or fundamental causes; the idea that power resides in the making of discourse and that language has the capacity to shape what it represents (be it the "orient," "sex," or "disablement"); and the inability to distinguish in principle between scientific rationality and the stuff of religious belief. We have not heard the last of the theory wars, and the search for "the soul of history" carries on.

But just as there are signals from Francophone intelligence and elsewhere of a return to the political, ${ }^{83}$ so there are signs in the practice of history that we have passed beyond the notion of a postmodern declension and the attendant fear that "a radical skepticism could yet defeat us all" (as Mary Douglas put it in the mid1980 s and the philosopher Peter Sloterdijk struggled against in his Critique of Cynical Reason). ${ }^{84}$ There are indications that we have superceded the would-be hegemonic neodeterministic view of language as the root of "what it is possible for people to think and do." ${ }^{85}$ To a considerable extent "postmodernism" has been desanctified, and there are clear signs that the."civil war" between discursivity and historicity, or more broadly between "the cultural" and "the social," has entered a more accommodating phase, less privileging of the cultural. ${ }^{86}$ For some historians, this largely means the recognition and reconciliation of these different categories, as in Beyond the Cultural Turn (1999) and Reconstructing History (1999), ${ }^{87}$ although these still attempt to rescue history from the perceived tight clutches of postmodern cultural studies. For others, it opens the way to de-polemicizing the debate between "discursivity" and "reality" in order to repoliticize it in terms of the political and ideological context in which it occurred. ${ }^{88}$ For still others, such as Antoinette Burton, campaigns like these serve only to validate the old disciplinary demarcations and to foster anew static, stolid, and unitary understandings of their natures. Burton demands, rather, that we inquire into the naturalizing use to 
which the categories "the social" and "the cultural" continue to be put in contemporary historiography. ${ }^{89}$ This idea cannot be developed here, but as it suggests, historiographical discourse has already moved beyond the postapartheid politics of the social versus the cultural. Indeed, as early as 1995, Catherine Casey, in Work, Self, and Society after Industrialism, provided a compelling illustration of how one might "return the social to critical theory" without necessarily discarding discourse analysis or returning to a conventional social analysis that merely privileges material social relations..$^{90}$ In many ways, this is the drift of some of the most engaging recent work in the history of medicine, though to call it "history of medicine" is to force it into increasingly anachronistic boxes. ${ }^{91}$

A review of this literature cannot be undertaken here, but three general points are worth making. The first is that it owes large debts to somatic cultural studies and, in particular, to Mary Poovey's Making a Social Body (1995)-a work that specifically challenged the idea that "the textual" and "the social" are antithetical or mutually exclusive domains of inquiry. ${ }^{92}$ Going beyond the earlier insights of Foucault and Jacques Donzelot on the formative role of medicine in the invention of "the social,"93 Poovey has demonstrated how the modernist abstract of the "social body" was itself generated in the early Victorian state in response to cultural and political anxieties about anatomy and contagion, poverty and disease. Subsequent studies, such as Erin O'Connor's Raw Material (2000), take this further, revealing the operation of constraining somatized metaphors not only in the Victorians' own social critiques (as in the writings of Thomas Carlyle) but also in such contemporary cultural practices as postcolonial discourse and its critique and, indeed, in the practices of cultural studies as a whole. ${ }^{94}$

Second, while none of this literature is intended to contribute to the social history of medicine or even to the history of medicine (despite publisher's classifications), it might be said to fulfill the erstwhile ambition of the subdiscipline to join the mainstream of history. As Jim Epstein remarked in a review of Poovey and similar studies: in the face of worry over postmodernism's threat to social history, such work powerfully testifies to "the very real openings available for writing new kinds of social and cultural history."95 Seen from this vantage, "the end" of the social history of medicine might almost be considered as that running from nemesis to omniscience.

Third, and finally, this literature brings us back to politics. For one thing, it marks a turning away from the over self-referential, hall-of-mirrors-type cultural studies of recent years, much of which was written for the sake of its own disciplinary ends or for the sake of illustrating interesting tensions in the literary history of modernity. It is not just that the new work firmly registers Foucault's point about the body as the place where (as O'Connor puts it) "power has historically assumed its most monstrous and its most liberatory incarnation. ${ }^{196} \mathrm{It}$ is also that the literature amplifying this point now often passionately embraces a belief in the transformative potential of cultural theory to force thinking beyond categorical constraints. Thus, for $\mathrm{O}^{\prime} \mathrm{Connor}$ (drawing strength from Haraway), cultural studies are a "radical and necessary form of activism," which is all the more driven by the realization that "genuinely searching academic work is fast becoming a vestigial structure, a useless and hence expendable appendage to a culture that neither values nor understands it."197 In a more straightforward way, Lawrence Driscoll, for instance, maps the Victorian discourse on drugs to expose how its cultural construction continues (devastatingly) to constrain social thought and political action. The point of Driscoll's discourse analysis is directly to effect political reform. ${ }^{98}$

Just as this literature helps us understand how "the social" was very largely invented and problematized within and through the vocabularies of medicine, so at a deeper level (if only by extension) it compels us to think about "the political" by encouraging the problematization of "the medical" as constitutive of "the social." "99 be blunt, we can no longer speak of "the political" or "the medical" or "the social" because we no longer know what holds these categories together. Such categories must now be seen as hypothetical at best; like "nature," they are labels that do not explain so much as beg explanation. Hence, the complex and diverse phenomenon called medicine cannot be said to exist inside "the political" or "the social," anymore than the political or the social can be said to exist within (or to structure) "the medical." It is only through the material organization of the objects and resources having to do with medicine that "the medical" and "the political" can be seen as held together or given agency, that is, through technologies, expertise, texts, architectures, and the material (actual) social relations that go with them. The latter would include not just the relations between doctors and patients but between doctors and doctors, patients and patients, doctors and families, researchers and the state, pharmaceutical companies and the law, and so on, and so on. Admittedly, these material relations of medicine are not the only connections between people, and they can be distinguished from those around, say, education, consumerism, religion, the military, diplomacy, and the law, even if they may often overlap or be in tension with them. Whether they are primary relations in a world as "medicalized" as ours may be open to debate; what is more important to stress here is the lack of any need to privilege them over discursive and epistemological considerations. The need, rather, is to understand that it is these material social relations that actually produce the political of which the 
emergent discourses and epistemologies of medicine (themselves capable of acting as material forces) are a part. In other words, like "the social," "the political" cannot be regarded as a transcendent category with assumed inherent force.

Happily, this leaves the territory and the practice of the history of medicine wide open, even if it collapses the old disciplinary boundaries. There is no basis for privileging "the cultural" over "the social" any more than there is reason to lord medical ethics over medical economics. And equally, there is the opportunity to revisit such old sites as professionalization, the idea of medical elites, the technical content of medical knowledge, and so on, whose recent loss to the history of medicine has been lamented. ${ }^{100}$ The prospect, then, at the end of the social history of medicine is not a return to what was lost when "the social" got retheorized and "framed" but rather to a different kind of poststructural "political" understanding of the phenomenon that is medicine within a historiographical frame that is more critically aware of its own values, perspectives, and aims.

NOTES

For helpful comments on an earlier version of this chapter, I'm grateful to John Arnold, Rhodri Hayward, Elsbeth Heaman, Rickie Kuklick, Bill Luckin, Eve Seguin, Sally Šheard, Steve Sturdy, and the participants in the conference at Maastricht where it was first aired. As ever, I am indebted to the Wellcome Trust for their generous support.

1. Charles Rosenberg, "Framing Disease: Illness, Society, and History," introduction to Framing Disease: Studies in Cultural History, Charles Rosenberg and Janet Golden, eds. (New Brunswick, N.J.: Rutgers University Press, 1992), xiii-xxvi. The introduction was a revised version of Rosenberg's "Disease in History: Frames and Framers," Milbank Quarterly 67 (1989): $1-15$

2. A sure sign was the commonplace appearance in the 1990s of "frames" and "framing" in applications for history of medicine funding. Further reflecting the term's vogue, as well as some of the significance of its use or nonuse, is Michael Worboys's Spreading Germs: Disease Theories and Medical Practice in Britain, 1865-1900 (Cambridge: Cambridge University Press, 2000), 12-13, where he submits that, to describe his approach, he has "chosen to use 'construction' rather than the currently more popular terms of social construction and
framing."

3. Andrew Wear, "Introduction," in Medicine in Society: Historical Essays, Andrew Wear, ed. (Cambridge: Cambridge University Press, 1992), 1-13, 1; Ludmilla Jordanova, "Has the Social History of Medicine Come of Age?" Historical Journal 36 (1993): 437-449. Of Jordanova's four criteria for determining a field's "maturity," her most substantial one-the conducting of sophisticated debates to encourage, refine, and, if necessary, radically alter interpretations-has remained largely unfulfilled within the social history of medicine (as
Godelieve van Heteren also noted in "Pourquoi Pas? The Absence of Radical Constructionism in the Social History of Medicine \& SHM's Critical Potentials," paper presented at "Medical History: The Story and Its Meaning," Maastricht, Netherlands, 16-18 June 1999.

4. See Carolyn Steedman, Dust (Manchester: Manchester University Press, 2002), esp. chap. 7, "About Ends: On How the End Is Different from an Ending."

5. John Pickstone, Ways of Knowing: A New History of Science, Technology, and Medicine (Manchester: Manchester University Press, 2000), 6.

6. Ludmilla Jordanova has repeatedly drawn attention to the definitional problem with the word, most recently in Nature Displayed: Gender, Science, and Medicine, 1760-1820 (London: Longman, 1999), esp. part 2, "Body Management," 101. In much of the historiography of medicine from Sprengel to Sigerist "medicine" was debated in terms of whether it was a "science" or an "art." See Charles Webster, "The Historiography of Medicine," in Information Sources in the History of Science and Medicine, Pietro Corsi and Paul Weindling, eds. (London: Butterworth Scientific, 1983), 29-43.

7. Nikolas Rose, "Medicine, History, and the Present," in Reassessing Foucault: Power, Medicine and the Body, Colin Jones and Roy Porter, eds. (London: Routledge, 1994), 48-72, 49.

8. Ludmilla Jordanova, "The Social Construction of Medical Knowledge," Social History of Medicine 8 (1995): 361-381, 362. See also John Harley Warner, "The History of Science and the Sciences of Medicine," Osiris 10 (1995): 164-193.

9. John Pickstone, "Medicine, Society, and the State" in Cambridge Illustrated History of Medicine, Roy Porter, ed. (Cambridge: Cambridge University Press, 1996), 304.

10. Rudolf Klein, "The Crises of the Welfare States," in Medicine in the Twentieth Century, Roger Cooter and John Pickstone, eds. (Amsterdam: Harwood Academic, 2000), 155-170; see also in this volume, John Pickstone, "Production, Community, and Consumption: The Political Economy of Twentieth-Century Medicine," 1-19.

11. James S. Kuo, "Swimming with the Sharks-the MD, MBA," The Lancet 350 (20 September 1997), 828.

12. Henrika Kuklick, "Professionalization and the Moral Order," in Disciplinarity at the Fin de Siècle, Amanda Anderson and Joseph Valente, eds. (Princeton: Princeton University Press, 2002), 126-152.

13. R. J. Lilford et al., "Medical Practice: Where Next?" Journal of the Royal Society of Medicine 94 (November 2001): 559-562.

14. Anne Hudson Jones, "Narrative Based Medicine: Narrative in Medical Ethics," British Medical Journal 318 (23 January 1999), 255. The use of the phrase in relation to ethics is symptomatic of the dominance in contemporary medical discourse of evidence-based medicine. See, for example, "Evidence-Based Art," Journal of the Royal Society of Medicine 94 (June 2001): 306-307.

15. Roy Porter, review of Foucault: Health and Medicine, Social History of Medicine 12 (1999): 178.

16. Simon Williams and Michael Calnan, "The 'Limits' of Medicalization?: Modern Medicine and the Lay Populace in 'Late' Modernity," Social Science and Medicine 42 (1996): 1609$1620,1616$.

17. Leigh Turner, "Medical Ethics in a Multicultural Society," Journal of the Royal Society of Medicine 94 (November 2001): 592-594. The political correctness of multiculturalism is of 
course another form of would-be universalistic morality. Rawls's notion of "moral consensus" compares with Richard Rorty's notion of "solidarity" or "community" among Western philosophers, a notion denounced as "an exemplar of the nationalist philosophy of a new world"; Michael Billig, Banal Nationalism (London: Sage, 1995), 11-12, 162ff.

18. Ulrich Beck, Risk Society: Towards a New Modernity, M. Ritter, trans. (London: Sage, 1992), and "The Reinvention of Politics: Towards a Theory of Reflexive Modernization" in Reflexive Modernization: Politics, Tradition, and Aesthetics in the Modern Social Order, U. Beck, A. Giddens, and S. Lash, eds. (Cambridge: Polity Press, 1994), 1-55.

19. Claudia Wiesemann, "Defining Brain Death: The German Debate in Historical Perspective," in Coping with Sickness, John Woodward and Robert Jütte, eds. (Sheffield: European Association for the History of Medicine and Health Publications, 2000), 149-169, 151

20. Williams and Calnan, "The 'Limits' of Medicalization."

21. See Tim Jordan, Activism! Direct Action, Hacktivism, and the Future of Society (London: Reaktion Books, 2002).

22. Rose, "Medicine, History, and the Present," 50

23. John Pickstone, "The Development and Present State of History of Medicine in Britain," Dynamis 19 (1999): 457-486, 484.

24. Lynn Hunt, "Does History Need Defending?" History Workshop Journal 46 (1998): 241.

25. Robert D. Putman, Making Democracy Work (Princeton: Princeton University Press, 1993), 8; Karl Marx, "The Eighteenth Brumaire of Louis Bonaparte [1858]," Pelican Marx Library: Political Writings, vol. 2: Surveys from Exile (Harmondsworth: Penguin, 1973), 146.

26. Peter Novick, That Noble Dream: The "Objectivity Question" and the American Historical Profession (Cambridge: Cambridge University Press, 1988).

27. Arthur Marwick, The Nature of History, 3d ed. (Basingstoke: Macmillan, 1989), and the sequel, The New Nature of History: Knowledge, Evidence, Language (Basingstoke: Palgrave, 2001); Bryan Palmer, Descent into Discourse. The Reification of Language and the Writing of Social History (Philadelphia: Temple University Press, 1990); Joyce Appleby, Lynn Hunt, and Margaret Jacob, Telling the Truth about History (New York: Norton, 1994); Richard Evans, In Defence of History (London: Granta Books, 1997); Geoff Eley, "Is All the World a Text? From Social History to the History of Society Two Decades Later," in The Historical Turn in the Human Sciences, Terrence J. McDonald, ed. (Ann Arbor: University of Michigan Press, 1996), 193-243; Eric Hobsbawm, “On History," in On History (London: Abacus, 1998), 351-366; Raphael Samuel, "Reading the Signs: Fact Grubbers and Mind Readers," History Workshop Journal 32 (1991): 88-109 and 33 (1992), 220-251; Gareth Stedman Jones, "The Determinist Fix," History Workshop Journal 42 (1996): 19-35; David Mayfield and Susan Thorne, "Social History and Its Discontents: Gareth Stedman Jones and the Politics of Language," Social History 17 (1992): 165-188.

28. The phrase is Daniel Cordle's; Postmodern Postures: Literature, Science, and the Two Cultures Debate (Aldershot: Ashgate, 1999).

29. Georg G. Iggers, Historiography in the Twentieth Century: From Scientific Objectivity to Postmodern Challenge (Hanover, N.H.: Wesleyan University Press, 1997). See also Poststructuralism and the Question of History, Derek Attridge, Geoff Bennington, and Robert Young, eds. (Cambridge: Cambridge University Press, 1987).

30. Mike Wallace, "Hijacking History: Ronald Reagan and the Statue of Liberty," Radical
History Review 37 (1987): 119-130. See also in this journal in the 1980s the regular feature on the "abusable past."

31. See Robert Hewison, The Heritage Industry: Britain in a Climate of Decline (London: Methuen, 1987); David Lowenthal, The Heritage Crusade and the Spoils of History (New York: Free Press, 1996); Tony Bennett, The Birth of the Museum: History, Theory, Politics (London: Routledge, 1995); Ludmilla Jordanova, "The Sense of a Past in Eighteenth-Century Medicine," The Stenton Lecture 1997 (University of Reading, 1999); idem, History in Practice (London, Arnold, 2000). See also Reconstructing History: The Emergence of a New Historical Society, Elizabeth Fox-Genovese and Elizabeth Lasch-Quinn, eds. (New York: Routledge, 1999), xvii.

32. Jean Baudrillard, In the Shadow of the Silent Majorities ... or the End of the Social, and Other Essays (New York: Semiotext(e), 1983). The social has been absorbed into the cultural, he argued, because "there is no longer any social signifier to give force to a political signifier," 19. Quoted in Catherine Casey, Work, Self, and Society (London: Routledge, 1995), 10.

33. Patrick Joyce, "The End of Social History," Social History 20 (1995): 73-91. For a lucid account of "the ending" in terms of its epistemological bankrupting, see Christopher Kent, "Victorian Social History: Post-Thompson, Post-Foucault, Postmodern," Victorian Studies 40 (1996): 97-133. With reference more to the epistemological wasteland of socialist historians in the wake of the end of the Marxist epic, see Raphael Samuel, "On the Methods of History Workshop: A Reply," History Workshop Tournal 9 (1980): 162-176, and discussion in Steedman, Dust, 79ff. For a more mundane account, see Evans, Defence of History, $168 \mathrm{ff}$.

34. Ulrich Beck, "How Modern is Modern Society," Theory, Culture \& Society 9 (1992): 163.

35. This is not to suggest that the Francophone philosophers and linguists were antiMarxists. Raphael Samuel ("Reading the Signs") hinted that many were, and the exposure in 1987 of one of the leading postmodern literary theorists, Paul de Man, as having had fascist connections during the occupation of Belgium during World War II (see Evans, Defence of History, 233ff) was seized upon by many as part of the hidden reactionary agenda of literary deconstructionists in their insistence on the irrelevance of authorial intentions in textual interpretations. But the attempt to lump postmodernists together on the right is no more convincing that the effort to tar them with leftist associations, as historian Arthur Marwick wants to suggest by his blanket dismissal of "Postmodernist/Marxist junk"; "All Quiet on the Postmodern Front: The 'Return to Events' in Historical Study," Times Literary Supplement, 23 February 2001, 13-14. Many of the francophone founders of discourse analysis were Marxists (for example Régine Robin, Michel Pêcheux, Denise Maldidier, Jean-Baptiste Marcellesi, Jacques Guilhaumou, and Jean Pierre Faye), though after May 1968 they became uncomfortable with the workers' movement and the preconceived historical explanations offered by dogmatic Marxists. There may be more truth to Marwick's assertion that "much of postmodernism appealed profoundly to those who were by no means politically radical." Marxist literary theorist Terry Eagleton had said as much in 1983, accusing deconstructionists of being intellectual elitists who savored signifiers over "what ever might be going on in the Elysee Palace or the Renault factories"; cited in Novick, That Noble Dream, 567, who also concedes that postmodern thought "was on the whole quite apolitical," 566 . On the antiMarxist tendency of poststructuralists, see Tony Bennett, "Texts in History: The Determina- 
tions of Readings and Their Texts" in Attridge, Bennington, and Young, Poststructuralism, 66-67. Nevertheless, the assault on modernity under the banner of différance was a part of a critique of the reifying rationality culture of late capitalism. Moreover, as the reaction to the "linguistic turn" suggests, there was nothing nonpolitical about adopting avant garde literary theory in the wake of the perceived exhaustion of the "political" 1970s.

36. Daniel Bell's classic The End of Ideology: On the Exhaustion of Political Ideas in the Fifties (New York, Free Press, 1960), appeared laughably anachronistic after 1968, but in 1988 it could be credibly reissued. For the context of Bell's work, see Job Dittberner, The End of Ideology and American Social Thought, 1930-1960 (Ann Arbor: UMI Research Press, 1979). Albert Camus apparently first used the phrase "end of ideologies" in 1946, referring to absolute utopias such as Marxist ones that destroy themselves. On the history of the utopian politics of an "end to politics," see Jacques Rancière, On the Shores of Politics, Liz Heron, trans. (London: Verso, 1995)

37. "The young conservatives embrace the fundamental experience of aesthetic modernity-the disclosure of a decentered subjectivity, freed from all constraints of rational cognition and purposiveness, from all imperatives of labor and utility-and in this way break out of the modern world. They thereby ground in intransigent antimodernism through a modernist attitude. They transpose the spontaneous power of the imagination, the experience of self and affectivity, into the remote and the archaic; and in manichean fashion, they counterpose to instrumental reason a principle only accessible via 'evocation': be it the will to power or sovereignty, Being or the Dionysian power of the poetic. In France this trend leads from Georges Bataille to Foucault and Derrida. The spirit [Geist] of Nietzsche that was reawakened in the 1970s of course hovers over them all"; Jürgen Habermas, "Modernity versus Postmodernity," New German Critique 22 (1981): 3-14, cited in Richard Wolin, "Introduction," Habermas, The New Conservatism: Cultural Criticism and the Historians' Debate, Sherry W. Nicholsen trans. and ed. (Cambridge: Polity Press, 1989), xxi-xxii.

In France, those called the "new philosophers" were André Glucksman, Alain de Benoist, Bernard-Henri Lévy, and Pascal Bruckner. All were opposed to totalitarianism in Europe, the seeds of which they saw in Marx and Hegel's philosophy; and some were deeply involved in human rights in Bosnia and elsewhere. My thanks to Eve Seguin for this information.

38. Much of this is recognizably pre-Thatcher 1960 s thinking (indeed, in some ways it echoes the postrationalist thought of the 1930s), but in general, in Anglo-American circles, the ideas of the "new philosophers" were taken up in the late 1970s and 1980s.

39. See Michel Foucault, Power/Knowledge: Selected Interviews and Other Writings, 19721977, Colin Gordon, ed. (Brighton: Harvester Press, 1980), 51, 57-58, 76. Foucault eschewed the label "postmodernist," and legitimately so, for as Rose points out, his "rejection of unities was not done in the name of a post-modern metaphysics that celebrates diversity, [but rather] in the light of a more sober and, dare one say, more historical conviction that that which 'is' is much less determined, much more contingent, than we think"; Rose, "Medicine, History and the Present," 70; see also Steven Best, The Politics of Historical Vision: Marx, Foucault, Habermas (New York: Guilford Press, 1995).

40. Foucault, Power/Knowledge, 89.

41. See Jonathan Joseph, "Derrida's Spectres of Ideology," Journal of Political Ideologies 6 (2001): 95-115.

42. Michel Foucault, Discipline and Punish, Alan Sheridan, trans. (London: Penguin, 1979), 25-26.
43. Simon During, Foucault and Literature (London: Routledge, 1992), 3. On the place of Foucault within the intellectual transformation of the 1980s, see Kent, "Victorian Social History," and Mitchell Dean, Critical and Effective Histories: Foucault's Methods and Historical Sociology (London: Routledge, 1994).

44. Michel Foucault, The History of Sexuality, Vol. 1: An Introduction, Robert Hurley, trans. (London: Penguin, 1990), 7-12.

45. Palmer, Descent into Discourse.

46. Ennesto Laclau, New Reflections on the Revolution of Our Time (London: Verso, 1990), see, in particular, chap. 2, "The Impossibility of Society."

47. John Law, "Editor's Introduction: Power/Knowledge and the Dissolution of the Sociology of Knowledge" in Power, Action, and Belief: A New Sociology of Knowledge? John Law, ed. (London: Routledge \& Kegan Paul, 1986), 3. See also Stuart Sim, Derrida and the End of History (Trumpington: Icon, 1999).

48. Two brilliant examples of the application of some of these postmodern concerns to historical material are Judith Walkowitz, City of Dreadful Delight: Narratives of Sexual Danger in Late-Victorian London (London: Virago, 1992), and Daniel Pick, War Machine: The Rationalisation of Slaughter in the Modern Age (New Haven: Yale University Press, 1993).

49. Donna Haraway, Simians, Cyborgs, and Women: The Reinvention of Nature (London: Free Association, 1991); Edward Said, Orientalism (New York: Pantheon, 1978) and Culture and Imperialism (New York: Knopf, 1993).

50. At a conference on "Dissolving the Boundaries: Historical Writing Towards the Third Millennium," University of Warwick, July 1997.

51. Mark Jenner, "Body, Image, Text in Early Modern Europe," Social History of Medicine 12 (1999): 143-154.

52. Williams and Calnan, "Limits of Medicalization," who conclude: "Without wishing to sound too post-modern, reality, in truth is a mess, and we would do well to remember this as we edge ever closer towards the twenty-first century!" Some explication of this "mess" is provided by Paul Barry Clarke, "Deconstruction," in the Dictionary of Ethics, Theology, and Society, P. B. Clarke and A. Linzey, eds. (London: Routledge, 1996), 216-223.

53. Geoff Eley and Keith Nield, "Why Does Social History Ignore Politics?" Social History 5 (1980): 267

54. Dorothy Porter, "The Mission of Social History of Medicine: An Historical View," Social History of Medicine 8 (1995): 345-359, 359. Cf. Charles Webster's call in 1983 for a social history of medicine "that would place its primary emphasis on the changing pattern of health of the population as a whole"; "The Historiography of Medicine," 40.

55. Ludmilla Jordanova, "The Social Construction of Medical Knowledge," Social History of Medicine 8 (1995): 363 , reprinted as chap. 15 in this volume.

56. Among them are Sander Gilman, Difference and Pathology: Stereotypes of Sexuality, Race, and Madness (Ithaca, N.Y.: Cornell University Press, 1985); Disease and Representation: Images of Illness from Madness to AIDS (Ithaca, N.Y.: Cornell University Press, 1988); The Jew's Body (London: Routledge, 1991); Inscribing the Other (Lincoln: University of Nebraska Press, 1991); Health and Illness: Images of Difference (London: Reaktion Books, 1995); and Making the Body Beautiful: A Cultural History of Aesthetic Surgery (Princeton: Princeton University Press, 1999).

57. Responding to one of the American critics of Adrian Desmond and Jim Moore's Darwin, Jim Moore remarked, "The ' $\mathrm{F}$ ' word today is flung about by critics like navvies 
flourish theirs. ... It would be a solecism to suppose that either of us owes anything to by Fouch ' by Foucault; Moore has repeatedly faulted Foucault-like accounts. ... We didn't need his advice on sucking epistemologcal eggs, nor indeed did the scholars whose work made Darwin possible." Journal of Victorian Culture 3 (1998): 152 . The latter point is also made by Jordanova in "The Social Construction of Medical Knowledge," 368-369. See also Jones and Porter, Reassessing Foucault.

58. Roger Cooter and Steve Sturdy, "Of War, Medicine, and Modernity: Introduction" in War, Medicine, and Modernity, Roger Cooter, Mark Harrison, and Steve Sturdy, eds. (Stroud:
Sutton, 1998), esp. 5 .

59. Jenner, "Body, Image, Text," 143-154; see also Mark Jenner and Bertrand Taithe, "The Historiographical Body," in Cooter and Pickstone, Medicine in the Twentieth Century, $187-200$.

60. Evidence of which lies with the nature of most of the books sympathetically reviewed by Martin Wiener in terms of their contribution to modern British history: "Treating 'Historical' Sources as Literary Texts: Literary Historicism and Modern British History," Journal of Modern History 70 (1998): 619-638.

61. Patrick Joyce, "The Return of History: Postmodernism and the Politics of Academic History in Britain," Past and Present 158 (1998): 212 n.18, cited (in more user-friendly format) in "The Challenge of Poststructuralism/Postmodernism" in The Houses of History: $A$ Critical Reader in Twentieth-Century History and Theory, Anna Green and Kathleen Troup, eds. (Manchester: Manchester University Press, 1999), 297.

62. See, for example, the case for the study of the laity in Cornelie Usborne and Willem de Blécourt, "Pains of the Past: Recent Research in the Social History of Medicine in Germany," Bulletin of the German Historical Institute London 21 (1999): 5-21.

63. See Jenner, "Body, Image, Text" 143. A more recent example is Roy Porter's Bodies Politic: Disease, Death, and Doctors in Britain, 1650-1900 (London: Reaktion Books, 2001), which, while nodding in the direction of "the body as text," is preoccupied with "contextualizing [visual material] within the wider cultural pool," 12. In this respect, as in others, Bodies Politic is, as Porter submits, a sequel to his previous social histories of the sick and the sick trade, 35 .

The most explicitly Foucauldian studies of the body were conducted not by social historians of medicine but by historically minded sociologists of medicine such as David Armstrong, Nikolas Rose, Deborah Lupton, and Bryan Turner: Armstrong, Political Anatomy of the Body: Medical Knowledge in Britain in the Twentieth Century (Cambridge: Cambridge University Press, 1983); Lupton, Medicine as Culture: Illness, Disease, and the Body in Western Societies (London: Sage, 1994) and The Imperative of Health: Public Health and the Regulated Body (London: Sage, 1995); Rose, Governing the Soul: The Shaping of the Private Self (London: Routledge, 1989); Turner, Medical Power and Social Knowledge, 2d ed. (London: Sage, 1995). See also, The Body: Social Process and Cultural Theory, Mike Featherstone, Mike Hepworth, and Bryan Turner, eds. (London: Sage, 1991). A notable exception among social historians writing on the body (and drawing heavily on sociology, anthropology, and political theory) was Barbara Duden, The Woman beneath the Skin: A Doctor's Patients in Eighteenth-Century Germany, T. Dunlop, trans. (Cambridge, Mass.: Harvard University Press, 1991), see esp.
chap. 1, "Toward a History of the Body."

64. Rosenberg, "Framing Disease," xiv.
65. For example, Robert A. Aronowitz, Making Sense of Illness: Science, Society, and Illness (Cambridge: Cambridge University Press, 1998).

66. Charles Rosenberg, "Disease and Social Order in America: Perceptions and Expectations," Milbank Quarterly 64, suppl. 1 (1986): 34-55, reprinted in AIDS: The Burdens of History, Elizabeth Fee and Daniel Fox, eds. (Berkeley: University of California Press, 1988), $12-32$.

67. Novick, That Noble Dream. Reference to many of the reviews of the book are noted in its discussion by Allan Megill: "Fragmentation and the Future of Historiography," American Historical Review 96 (1991): 693-698.

68. See Christopher Norris, Against Relativism: Philosophy of Science, Deconstruction, and Critical Theory (Oxford: Blackwell, 1997), 102. On Lyotard, see also the special issue of Parallax 6 (2001): 1-145.

69. For many historians, Novick observes, "what has been at issue is nothing less than the meaning of the ventures to which they have devoted their lives, and thus, to a very considerable extent, the meaning of their own lives. 'Objectivity' has been one of the central sacred terms of professional historians, like 'health' for physicians, or 'valor' for the profession of arms"; That Noble Dream, 11, see also $564 \mathrm{ff}$.

70. Cited in Mary Douglas, "The Social Preconditions of Radical Skepticism," in Law, Power, Action, and Belief, 68-87, 81.

71. Liz McMillen, "The Science Wars Flare at the Institute for Advanced Study," Chronicle of Higher Education, 16 May 1997. The spark for this particular conflagration was Gerald Geison's demythologizing, contextualizing, and social-constructivist-tending biography of Pasteur, The Private Science of Louis Pasteur (Princeton: Princeton University Press, 1995).

72. Rosenberg, "Framing Disease," xv. As it emerged, substituting "frame" for "social" was all the more politically expedient for those applying for research funding in this charged environment.

73. See, in particular, Erving Goffman, The Presentation of Self in Everyday Life (New York: Doubleday, 1959). "Framing," of course, had and has other lives in medicine and elsewhere; see, for example, Harry Collins and Trevor Pinch, Frames of Meaning: The Social Construction of Extraordinary Science (London: Routledge, 1982), and Adrian Edwards et al., "Presenting Risk Information: A Review of the Effects of 'Framing' and Other Manipulations on Patient Outcomes," Journal of Health Communication 6 (2001): 61-82.

74. For an illustration of this use of framing as a descriptive category within an alleged historical case of "framing" for the avoidance of attributing blame or attaching responsibility to any particular interest group, see Chris Feudtner, "'Minds the Dead Have Ravished': Shell Shock, History, and the Ecology of Disease Systems," History of Science 31 (1993): 377-420. Feudtner draws explicitly on Rosenberg's concept of framing to avoid what "seems irresponsible[,] to dismiss shell shock as 'myth' or 'social construct,', 380.

75. Simon Schaffer, "A Social History of Plausibility: Country, City, and Calculation in Augustan Britain," in Rethinking Social History: English Society 1570-1920 and Its Interpretation, Adrian Wilson, ed. (Manchester: Manchester University Press, 1993), 133.

76. Rosenberg, "Disease and Social Order," 29 (my italics).

77. Cited in Frederic Jameson, Postmodernism, or the Cultural Logic of Late Capitalism (London: Verso, 1991), 397.

78. Ibid., 398.

79. Nick J. Fox, "Derrida, Meaning, and the Frame," in Beyond Health: Postmodernism and 
Embodiment (London: Free Association, 1999), 134-135. See also John Frow, who has deployed "the frame" to mark off a literary space which establishes "the particular historical distribution of the 'real' and the 'symbolic' within which the text operates." For Frow the frame organizes the "inside" and the "outside" of a text and the relations between them; the function of the frame is culturally dependent. Frow, "The Literary Frame," Journal of Aesthetic Education 16 (1982): 25-30.

80. For a critique of the social history of medicine as merely elaborating "full and appropriate contexts," see Roger Cooter, "Anticontagionism and History's Medical Record," in The Problem of Medical Knowledge: Examining the Social Construction of Medicine, Peter Wright and A. Treacher, eds. (Edinburgh: Edinburgh University Press, 1982), 87-108.

81. See Karl Figlio, "Second Thoughts on 'Sinister Medicine,'” Radical Science Journal 10 (1980): 159-166, 165.

82. A partial and peculiar recent exception is David Harley, "Rhetoric and the Social Construction of Sickness and Healing," Social History of Medicine 12 (1999): 407-435, to which Paolo Palladino has replied "And the answer is . . 42," Social History of Medicine 13 (2000): 142-151.

83. See Democracy and Nature 7 (March 2001), especially the contributions by Simon Tormey, "Post-Marxism," and Takis Fotopoulos, "The Myth of Postmodernity," 27-76.

84. Douglas, "Social Preconditions," 86. "The intellectual position of the relativists," she added, "can be shown to be contingent on their sense of futility or immorality of exercising power and authority, and this contingency rests in turn on their place in a social structure." Peter Sloterdijk, Critique of Cynical Reason (Minneapolis: University of Minnesota Press, 1987).

85. Bryan Palmer, "Is There Now, or Has There Ever Been, a Working Class?" in After the End of History, Alan Ryan, ed. (London: Collins and Brown, 1992), 100. See also Appleby et al., Telling the Truth about History, 230.

86. See, for example, A Cultural Revolution? England and France, 1750-1820, Colin Jones and D. Wahrman, eds. (Berkeley: University of California Press, 2002).

87. Beyond the Cultural Turn, Victoria E. Bonnell and Lynn Hunt, eds. (Berkeley: University of California Press, 1999); Fox-Genovese and Lasch-Quinn, Reconstructing History. See also, Gill Valentine, "Whatever Happened to the Social? Reflections on the 'Cultural Turn' in British Human Geography," Norwegian Journal of Geography 55 (2001): 166-172.

88. Geoff Eley and Keith Nield, "Farewell to the Working Class?" International Labour and Working-Class History 57 (2000): 1-30, and "Reply: Class and the Politics of History," ibid. 57 (2000): 76-87.

89. Antoinette Burton, "Thinking Beyond the Boundaries: Empire, Feminism, and the Domains of History," Social History 26 (2001): 60-71. See also Carolyn Porter, "History and Literature: 'After the New Historicism,'” New Literary History 21 (1990): 253-272.

90. Casey, Work, Self, and Society, 11. Casey's study is also one of the most lucid on the relations between postmodern theory and the politics of late capitalism.

91. Among examples of this work, not cited below, are Andrew Aisenberg, Contagion: Disease, Government, and the "Social Question" in Nineteenth-Century France (Stanford: Stanford University Press, 1999), and Ian Burney, Bodies of Evidence: Medicine and the Politics of the English Inquest, 1830-1926 (Baltimore: Johns Hopkins University Press, 2000). 92. Mary Poovey, Making a Social Body: British Cultural Formation, 1830-1864 (Chicago:
University of Chicago Press, 1995). Ian Burney's debts to Poovey are made explicit in his contribution to the roundtable discussion "The Making of a Social Body," Journal of Victorian Culture 4 (1999): 104-116.

93. Michel Foucault, "An Ethics of Pleasure," in Foucault Live: Interviews, 1966-84, S. Lotringer, ed. (New York: Semiotext(e), 1989), 261, cited in Gavin Kendall and Gary Wicham, "Health and the Social Body" in Private Risks and Public Dangers, Sue Scott et al., eds. (Aldershot: Avebury, 1992), 8-18, 9-10; Jacques Donzelot, L'invention du social (Paris: Fayard, 1984).

94. Erin O'Connor, Raw Material: Producing Pathology in Victorian Culture (Durham: Duke University Press, 2000). Cholera, breast cancer, amputations, and monsters are among the tropes she critically explores.

95. "Signs of the Social," Journal of British Studies 36 (1997): 473-484, 483.

96. O'Connor, Raw Material, 215.

97. Ibid., 214.

98. Lawrence Driscoll, Reconsidering Drugs: Mapping Victorian and Modern Drug Discourses (New York: Palgrave, 2000).

99. The best discussion of these matters is still Rose, "Medicine, History, and the Present."

100. By John Harley Warner, who perceives their study as having been delegitimized, not by the force of postmodernism, but by too great an emphasis on the history of science. Warner, "History of Science," 173. 